\title{
The attitudes of the island local community towards sustainable tourism development - the case of Stari Grad, island Hvar
}

\author{
L. Petrić \& L. Pranić \\ Faculty of Economics Split, University of Split, Croatia
}

\begin{abstract}
Islands, as an outstanding nature's work of art, have traditionally been popular tourist destinations. Considering their fragile environment and pressure that tourism development poses upon their economy, environment, and people in general, achieving sustainable tourism development is a major challenge they face. Yet, little research focusing on understanding small islands' residents' attitudes towards tourism and its effects have been conducted in the literature so far. This is especially the case with Croatian islands' communities where tourism has been developed almost spontaneously and as such is taken for granted. To fill this gap, this study examines the residents' attitudes towards tourism development in the town of Stari Grad on the island of Hvar.
\end{abstract}

Keyword: island destinations, sustainable tourism development, community attitudes, Stari Grad-Hvar.

\section{Introduction}

Most of the islands are small and uninhabited; many of them consist of several small communities counting in average not more than several hundred to several thousand inhabitants. Finally there are islands representing independent microstates of less than a million people (Mauritius, Malta, Bahamas etc.). However, regardless of the islands' size, their economies share following characteristics: they are small scaled, isolated and weak, oriented traditionally to agriculture and fishing with a very few ones making exemptions, e.g. having more diversified economies. Hence, it is not surprising that most of the islands have embraced tourism as a rare and unique development opportunity. Tourism is generally more important in an economic sense to an island destination than is usually the 
case with mainland destinations because it is invariably a larger and a more significant part of the island destination's economy. However it is also more pervasive in its impacts on the small island communities than is on larger mainland resort destinations. Considering their fragile ecological and sociocultural environment and pressure that tourism development poses upon their economy, environment, and people in general, achieving sustainable tourism development is a major challenge they face.

The concept of sustainable development has attracted debate and analysis from virtually all academic standpoints. In parallel with the evolution of sustainable development discourse, concerns about the environmental and social impacts of tourism have escalated in recent years. Many authors [7, 9, 25, 48] have recommended a number of principles that ought to be followed for sustainable tourism development. These include preservation of ecological processes and the protection of biodiversity in the natural realm and, in human terms, preservation of cultural integrity, holistic planning, balance, harmony, efficiency, equity and participation. Obviously, sustainability refers to the capacity for continuance of any destination and is, therefore, a function of complex relationships between society and natural resources, of socioeconomic and political structures and local-scale management decisions. Above all, sustainability in development of a tourist destination depends on recognition and utilization of local social and institutional capital [44].

Although locals appreciate tourism and most often recognize both its positive and negative impacts, implementation of the principles of sustainability in the process of tourism development in the small island communities is a special challenge since each island community exhibits unique characteristics. Although there has been quite an amount of literature dealing with the issues of local communities' attitudes towards tourism development, such researches in small island communities seem to be lacking, especially in Croatia, whose island portfolio is one of the richest in the world, with more than thousand of different sized islands, 66 of which are inhabited. Therefore, by drawing from current literature on small communities' economies, tourism dependency, and theoretical frameworks that have been applied to the study of host attitudes toward tourism, this study proposes a model for analyzing community attitudes toward tourism in small island communities with a special regard to the community of Stari Grad on the Croatian island of Hvar. Specifically, this research sought to accomplish these goals:

- Theoretically explore the concept of sustainable development and its application on the small island economies;

- Empirically investigate residents' attitudes towards costs and benefits arising from tourism development in the town of Stari Grad on the island of Hvar;

- Empirically examine the relationships between residents' attitudes and their socio-demographic characteristics. 


\section{Present state of tourism development in Stari Grad}

Before discussing the research methodology and results gained from the empirical research, a brief review of the current state of tourism development in the town of Stari Grad is presented. This overview sets the background for the opinions of the local residents towards the impacts of tourism on their community.

Stari Grad (ancient Pharos) is one of the oldest European towns and the oldest town on the island of Hvar, founded by the Ancient Greeks in 385/384 BC. It features beautiful nature and extraordinary cultural monuments. Following the demise of the former Yugoslavia and its command economy, a few small factories that did operate in Stari Grad up to that point, were closed. Today, with the exception of fishing and wine and olive growing, tourism is the only activity available to 1,906 local residents [13]. However, apart from its cultural and natural resources, the town has no financial and human potential to develop tourism according to the market requirements. Namely, between 1970s and 1990s, the prevailing concept of tourism development on the entire island of Hvar was sun-sea-sand tourism. However, after 1990s, not only because of the war consequences (hosting of the refugees in hotels and loss of markets), but also because of the shift of the demand due to the change of tourists' needs and preferences, the popularity of Stari Grad as a tourist destination has dwindled. Croatia's national hotel privatization process, instead of rejuvenating the hotel sector, only worsened this situation. Thus all the hotels are in a poor condition and able to cater only to the low-budget guest. Overall, no investments into the existing or new accommodation capacity have taken place during the past 20 years. Compared to the town of Hvar which recorded almost half a million of tourist overnights, the town of Stari Grad registered (for the first nine months) only 189,000 overnights [16]. Local tourist board and the local authorities do not know how to cope with this situation. Local residents feel hopeless and helpless with no means and no knowledge as to how to help resolve this development crisis, although they feel that tourism has great importance for their community!

A number of studies in recent years have examined host residents' perceptions of the impact of tourism development on their community. According to Gursoy and Rutherford [23], a number of these studies have used the Social Exchange Theory (SET), as a theoretical framework in assessing residents' attitudes toward tourism. It is "a general sociological theory concerned with understanding the exchange of resources between individuals and groups in an interaction situation" [4, as seen in 45].

Tourism has been most usually seen as a positive agent of change for many communities because of its potential for job creation, income generation, and enhanced community infrastructure [3, 5, 22]. However, while tourism development is usually justified on the basis of these positive benefits, it is often challenged on the grounds of socio-cultural and environmental devastation. Many researchers who investigate host community's attitudes toward tourism and support for tourism, study the perceived impacts of tourism (e.g., $[6,8])$. 
Residents' perceptions have been shown to be influenced by a number of factors, including: personal economic reliance on the tourism industry, the importance of the industry to the locality, the type and extent of resident-visitor interaction, and the overall level of tourism development in the community [38].

More specifically, research has shown that greater length of residency in the community [33, 34], and native-born status [18, 50] have been linked to greater negative perceptions of tourism. A few studies have focused on the relationship between the so-called community attachment and attitudes toward tourism [26]. Community attachment is defined as the "extent and pattern of social participation and integration into community life, and sentiment or affect toward the community" [35]. Community attachment has often been measured as length of stay and /or having been born or grown up there [36], sentiment about the community and involvement in the community.

Economic reliance has been linked to more positive perceptions of the tourism industry [34, 37]. On the other side, some researchers showed that socioeconomic variables appear to have little relationship to residents' perceptions of development [33, 34]. Just opposite to this, there are some researchers suggesting that gender [14, 37], occupation/education $[1,28]$ and age $[14,47]$ can explain attitudes toward tourism.

It is most often presumed that those residents who believe that they benefit from tourism are likely to view it positively while those who perceive costs will view it negatively. Residents who view tourism as personally valuable and believe that the costs do not exceed the benefits will favor tourism as a local development strategy [32]. Such residents have been found to display positive attitudes to tourism and be supportive of future tourism development in their community [4, 24]. Many small island communities have been going through substantial changes in their economy and the primary industries on which their economy depended have departed, leaving behind economic difficulties and the search for alternative development strategies. For instance, in a depressed island economy, residents might need to struggle for a living and might not be in favor of tourism but may still engage in its development due to the lack of other opportunities. Kayat [30] notes that such residents tend to be more positive toward the industry which might not always be attributed to the increased dependence on tourism, but on the fact that these dependent residents have no alternative, other than tourism to sustain themselves. Similarly, residents depending on tourism who display negative attitudes toward the industry might believe that their local economy is strong enough not to depend on tourism and to enable them earn a living from industries other than tourism. Consequently, such residents, though dependent on tourism, might not support the industry. This might be an explanation for the negative attitudes held by those residents who are dependent on tourism. This suggests that there are other factors such as the perceived state of the local economy which might be moderating the effect of tourism dependence on perceived tourism impacts.

In line with our study's goals, and based on the previous discussion, this study's main research hypothesis and a number of sub-hypotheses are as follows: 
H1: The residents of Stari Grad perceive economic impacts of tourism on their community to be positive.

Hla: A direct positive relationship exists between residents' community attachment and their attitudes towards economic impacts of tourism on Stari Grad

H1b: A direct relationship exists between residents' age and their attitudes towards economic impacts of tourism on Stari Grad

H1c: A direct relationship exists between residents' gender and their attitudes towards economic impacts of tourism on Stari Grad

H1d: A direct positive relationship exists between residents' employment in tourism and their attitudes towards economic impacts of tourism on Stari Grad

H1e: A direct positive relationship exists between the importance of tourism to residents' occupation and their attitudes towards economic impacts of tourism on Stari Grad

H1f: A direct positive relationship exists between seasonality of employment and residents' attitudes towards economic impacts of tourism on Stari Grad

H2: The residents of Stari Grad perceive social impacts of tourism on their community to be negative.

This hypothesis has been divided into a number of sub-hypotheses in much the same way as H1. However, instead of economic impacts, these sub-hypotheses span the relationship between socio-demographic and economic characteristics of the residents and selected social impacts. They range from $\mathrm{H} 2 \mathrm{a}$ to $\mathrm{H} 2 \mathrm{f}$.

H3: The residents of Stari Grad perceive environmental impacts of tourism on their community to be negative.

This hypothesis has been divided into a number of sub-hypotheses, ranging from $\mathrm{H} 3 \mathrm{a}$ to H3f, investigating the relationship between socio-demographic and economic characteristics of the residents and selected environmental issues.

\section{Research methodology}

The sampling frame for this study comprises 1,906 residents of the town of Stari Grad on the Island of Hvar in Croatia (2001 Population Census). This study's convenience sample totaled 200 residents and achieved a $66 \%$ response rate $(n=132)$. This figure allows for $95 \%$ confidence within $\pm 10 \%$ margin of error [27]. The survey instrument used in this study was comprised of a subset of items adopted and adapted from previous research [43, 45] and several new items, followed with a review by two social science research experts. Questionnaire design followed the established guidelines for mail surveys [20]. A resident of Stari Grad hand distributed 200 envelopes to an equal number of households throughout Stari Grad during October of 2009. Each envelope comprised a 2-page self-completed questionnaire written in Croatian, accompanied by a pre-stamped and pre-addressed return envelope. The questionnaire consisted of two sections. The first section included 7 socioeconomic and demographic items (predictor variables), such as gender, age, education, length of residence in Stari Grad on an annual basis, member (other than the respondent) of household employed in the tourism industry, seasonality 
of employment for the other household member employed in tourism, and the importance of tourism to the respondent's occupation.

Section two of the survey required respondents to rate their level of agreement with 22 tourism impact statements (response variables), with 8 items (V8-V15) representing economic impacts, 6 items (V16-V21) for social impacts, and 8 items (V22-V29) for environmental impacts. All respondents were required to rate their level of agreement with the selected statements on a 5-point Likert scale, ranging from 1 (strongly disagree) to 5 (strongly agree). Once collected, all data were entered into SPSS for further analyses.

\section{Findings}

Due to restrictions in the number of pages allowed, this section has been summarized for brevity. For detailed findings, please contact the authors.

\subsection{The study sample}

The majority of respondents were between the ages of 30 and $59(73 \%)$ and women (61\%). An overwhelming majority of survey participants $(90 \%)$ reside between 9 and 12 months on an annual basis in Stari Grad. Conversely, very few respondents live elsewhere (not in Stari Grad) during the year. Just over half of the sample (52\%) had earned an elementary and/or high school degree, while $48 \%$ held an associate's degree or higher. Fifty three percent of the sample indicated that a member of their household was currently employed in the tourism industry. Moreover, $27 \%$ of respondents claimed year-round employment in tourism, whereas $18 \%$ were seasonally employed. In addition, $60 \%$ felt that the tourism industry was either important or very important to their occupation. Overall, there are some differences between the profile of the respondents and the actual socio-demographics of Stari Grad's population, as per the last population census in 2001. For instance, women are overrepresented in this study's sample - i.e., $61 \%$ vs. $51 \%$ reported in census. On the other hand, in terms of age breakdown, the ' 29 and under' and ' 60 and over' groups are underrepresented in this study (17\% sample vs. 35\% census and $10 \%$ sample vs. $25 \%$ census, respectively). Other than for age and gender, attempts to test the representativeness of the sample for other socio-demographic variables (education, length of residence, tourism employment, employment seasonality, and importance of tourism to occupation) were unsuccessful because of lack of official data for Stari Grad.

\subsection{Resident perceptions}

From residents' responses to 22 tourism impact statements, respondents generally perceive that tourism for the most part favorably impacts community's economy and the environment, whereas social impacts are viewed as mostly negative. Specifically, items V11, V13 and V14 are considered tourism's negative economic impacts. As an example, residents feel that tourism had little success in incorporating agriculture into tourism supply (V14). In regards to 
tourism's impacts on the environment, V23, and V25 are deemed unfavorable. For instance, respondents believe that tourism did not contribute much in increasing environmental awareness among local residents. For social impacts, only V19, and V20 are judged positive. Thus, tourism resulted in broader appreciation for other people and cultures. Based on these findings, H1 and H2 appear as mostly supported, while H3 mainly lacks support.

\subsection{Residents' attitudes to tourism impacts and respondent characteristics}

Due to violation of the normality of distribution assumption, to test if there were any relationships between respondents' characteristics and the attitudes towards tourism impacts, the nonparametric Mann-Whitney $\mathrm{U}(\mathrm{M}-\mathrm{W} \mathrm{U})$ and KruskalWallis $(\mathrm{K}-\mathrm{W})$ tests were employed because they do not assume data normality. In the results of the $\mathrm{M}-\mathrm{W} \mathrm{U}$ and $\mathrm{K}-\mathrm{W}$ tests, not many statistically significant differences were evident as residents displayed quite a high degree of similarity in their attitudes. However, some groups exhibited some differences. Annual length of residence was a discriminator for four of the statements. For instance, those living more than 9 months per year (year-round) in Stari Grad showed stronger agreement with the statement that tourism has helped incorporate agriculture into tourism, as compared to those who live 3 or more months per year (part-time) elsewhere (not in Stari Grad). Gender was significant as an explanatory variable of attitude for only four statements. Education was significant for only one statement. Concerning reliance on tourism employment, four variables exhibited significant relationships. Age was not a significant discriminator with the exception of two statements.

The greatest contrast in views was found between residents employed seasonally in tourism vs. those employed year-round. Of the total 12 statistically significant statements, significance was evident in 6 out of 8 statements representing economic impacts, 3 out of 6 social impacts, and 3 out of 8 environmental impacts. For all but one of the 12 significant statements, yearround employees expressed a stronger agreement than seasonally employed residents. Specifically, year-round employees subscribed less frequently to the idea that tourism caused a loss of cultural identity. Overall, while year-round employees were more likely to perceive favorable economic and social impacts of tourism, they also suggested more frequently that tourism exhibited negative impacts on the environment. Thus, year-round employees agreed more strongly that presence of same-day visitors and tourist overcrowding endanger the town's environment. In addition to seasonality of employment, importance of tourism to occupation was significant as an explanatory variable for seven statements, with 4 out of 8 statements representing economic impacts having significance. Overall, in terms of this study's sub-hypotheses, H1a-H1d, H2a-H2e, and H3aH3f appear mostly unsupported. On the other hand, H1e-H1f and H2f seem mostly supported. 


\subsection{Reliability and validity}

Since the concept of measurement is crucial to scientific inquiry, reliability and validity are important aspects of survey research that must be addressed $[11,17]$. Cronbach's Coefficient Alpha is by far the most popular way to assess scale reliability [11] and is commonly used to establish convergent (construct) validity [23]. The results of reliability analysis indicate that the Coefficient Alpha [11] for the overall 22-item scale is .87. In terms of subscales, Alpha equals .82, .48. and .78 for economic, social, and environmental impacts, respectively. Thus, Alpha value for the social impacts scale is the only scale that appears below the minimum acceptable guideline of .70 for new scales [19, 40]. Since low Cronbach's Alpha indicates data multi-dimensionality, running a factor analysis was necessary in order to see which items load highest on which dimensions, and then the alpha of each subset of items was taken separately. Results confirmed that the data indeed were not unidimensional. The Cattell scree test [12] and the "Eigenvalue $>1$ " criterion [30] suggested a 2 factor solution accounting for $65.4 \%$ of the variance. Using a factor loading cutoff of .50, items V16, V18, and V19 did not seemingly measure the same latent construct as V17, V20, and V21. The separate estimation of reliability for these two subsets of items produced an acceptable Cronbach's Alpha .71 for the first subset and .68 for the second subset. Since both estimates of reliability were higher than when using all 6 items for measuring the same construct, V16, V18, and V19 should be combined to create one scale, while V17, V20, and V21 should be combined to create a second scale.

To assess (divergent) validity, all 22 items were factor analyzed in an attempt to discover underlying patterns in data without sacrificing the data's original integrity. During the analysis, item V24 showed a relatively low anti-image correlation (.565) with other items [29]. Thus, it was dropped from the factor analysis. This item was: 'The construction of hotels and other tourism facilities resulted in destruction of the natural environment'. The Kaiser-Meyer-Olkin measure of sampling adequacy was .834 , and the Bartlett's test of sphericity was significant $\left(X^{2}=1421.600, d f=210, p<.001\right)$. Both of these measures indicated that the data were appropriate for factor analysis [39, 42]. Moreover, the Cattell scree test and the "Eigenvalue $>1$ " criterion suggested a 4-factor solution accounting for $65.4 \%$ of the variance.

Factor 1 accounts for the most of the variance $(34.7 \%)$, whereas the second accounts for $13.5 \%$ and the third for $11.7 \%$. The fourth factor accounts for only $5.3 \%$ of variance in the data. Moreover, the communality estimates $\left(h^{2}\right)$ for this solution are acceptable, although the somewhat lower value of V15 (.551) shows that it does not fit as well as the others. Using a factor loading cutoff of .50, the factor loadings indicate that, for the most part, the scale representing economic impacts (V8-V12 and V14-V15) loads on a separate factor. Within the economic impacts scale, one item (V9) loads on more than one factor, while another item (V13) loads on a different factor. Environmental impacts (V23-V29) may actually be two subscales, with V24/V25/V28 and V23/V26/V27/V29 loading on different factors. Moreover, one item (V22) belonging to the environmental 
impacts scale loads on a separate factor. Items V18/V21 load on a factor representing 'social impacts', while V16, V19, and V20 - although items belonging to the social impacts scale - load on the other three factors. Overall, only one observed variable loaded on more than one factor and no observed variable loaded on all four factors.

\section{Conclusions and policy implications}

Overall, this study's findings highlight the complexity of tourism impacts on Stari Grad. On one hand, residents perceive that tourism for the most part favorably impacts community's economy and the environment. Social impacts, on the other hand, are viewed as mostly negative. Furthermore, while sociodemographic characteristics generally did not explain variations in residents' attitudes to any significant degree, there were few significant exceptions. Specifically, residents employed year-round in tourism were more likely to perceive favorable economic and social impacts of tourism. Yet, at the same time they also expressed concern about the negative environmental impacts of tourism. Is this possible because year-round employees in tourism are more aware and informed about tourism costs and benefits, in contrast to their seasonally employed counterparts? Also, residents who rated tourism as important to their occupation, perceived positive economic impacts from tourism. In order for the appropriate policy implications to be elicited in the future, further research is necessary to address this issue. In contrast to the majority of past research (e.g., [1, 14, 28, 33, 34, 37, 47]), this research found that age, gender, education, length of residence, and employment in tourism did not significantly affect residents' perceptions within the sample.

From a methodological perspective, a limitation of this study is that the addition of other indicators may have changed the results of the study, as well as the outcome of the factor analysis. While the economic impacts scale used in this study appears robust in this and other studies (e.g., [1]), the environmental impacts scale and - especially, the social impacts scale - may need further calibrating. Indeed, the factor analysis revealed that there was not a distinct factor extracted for the social impacts. Thus, future research should develop improved scales to acknowledge fully the whole range of issues for host communities. In terms of future research direction, since tourism development and its effects are a dynamic process, a research of Stari Grad residents' perceptions in ten years time seems warranted to measure change over time. Such longitudinal monitoring would likely provide invaluable insights for developers and planners into the community's perceptions of tourism impacts. They would then be able to take action aimed at increasing the community's welfare and anticipate any resentment towards incoming tourists.

In conclusion, residents' affirmative perceptions of tourism and its impacts are critical drivers of destination's long-term success. Therefore, it is pivotal that local population is involved in the community's development and planning process. This will however, require stronger commitment on the part of governments (on all the levels), developers, interest groups and community 
members themselves. With an increase in political, social, economic and psychological empowerment along these lines among residents and other stakeholders, tourism will have the potential to help meet local needs for development, bringing to fruition many of the goals of sustainability, including harmony, equity, balance, cultural integrity, and ecological conservation [49].

\section{References}

[1] Andriotis, K. (2004). The Perceived Impact of Tourism Development by Cretan Residents, Tourism and Hospitality Planning \& Development, 1(2), pp. 123-144.

[2] Andriotis, K. (2005). Community groups' perceptions of and preferences for tourism development: Evidence from Crete. Journal of Hospitality and Tourism Research 29(1), pp. 67-90.

[3] Andriotis, K. and Vaughan, D. R. (2003). Urban residents' attitudes towards tourism development: the case of Crete. Journal of Travel Research. 42(2), pp. 172-85.

[4] Ap, J. (1992). Residents' perceptions on tourism impacts. Annals of Tourism Research 19, pp. 665-690.

[5] Bender, M.Y., Deng, Y., Selin, S., Arbogast, D. and Hobbs. R. A. (2008). Local Residents' attitudes towards potential tourism development: the case of Ansted, West Virginia, Proceedings of the 2008 Northeastern Recreation Research Symposium, pp. 85-94

[6] Besculides, A., Lee, M. and McCormick, J. (2002). Residents' perceptions of the cultural benefits of tourism. Annals of Tourism Research 29(2), pp. 303-319.

[7] Bramwell, B. and Lane, B. (1993). Sustainable tourism: An evolving global approach. Journal of Sustainable Tourism, 1(1), pp. 1-5

[8] Brunt, P., and Courtney, P. (1999). Host perceptions of socio-cultural impacts. Annals of Tourism Research, 26(3), pp. 493-515.

[9] Butler, R.W. (1999) Sustainable tourism: A state-of-the-art review. Tourism Geographies, 1(1), pp. 7-25

[10] Caneday, L. and Zeiger, J. (1991) The social, economic, and environmental costs of tourism to a gaming community as perceived by its residents. Journal of Travel Research, 30(2), pp. 45-9.

[11] Carmines, E. G. and Zeller, R. A. (1979). Reliability and Validity Assessment. Thousand Oaks, CA: Sage Publications.

[12] Cattell, R. B. (1966). The scree test for the number of factors. Multivariate Behavioral Research, 1(2), pp. 245-276.

[13] Census. (2001). Republic of Croatia - Central Bureau of Statistics: 1. Population by sex and age, by settlements, Census 2001. Retrieved December 19th, 2009, from http://www.dzs.hr/Eng/censuses/Census2001 /Popis/E01_01_01/e01_01_01_zup17-4138.html.

[14] Chen, J. S. (2000) An investigation of urban tourism residents' loyalty of tourism. Journal of Travel and Tourism Research. 24(1), pp. 5-19. 
[15] Cook, T. D. and Campbell, D. T. (1979). Quasi Experimentation: Design and Analytical Issues for Field Settings. Chicago, IL: Rand McNally.

[16] Croatian Bureau of Statistics. (2009). Tourism - Cumulative Data: January-September 2009. Retreived December 19th, 2009, from http://www.dzs.hr/Eng/Publication/2009/4-4-2_8e2009.htm.

[17] Davis, D., Allen, J. and Cosenza. R. M. (1988). Segmenting local residents by their attitudes, interests and opinions toward tourism. Journal of Travel Research, 28(2). pp. 2-8

[18] DeVellis, R. F. (2003). Scale Development (2nd ed.). Thousand Oaks, CA: Sage Publications.

[19] Dillman, D. A. (2000). Mail and Internet Surveys: The Tailored Design Method (2nd ed.). New York, NY: John Wiley \& Sons, Inc.

[20] Dong-Wan, K. and Stewart, W.P. (2002). A structural equation model of residents' attitudes for tourism development. Tourism Management 23(5), pp. 521-530

[21] Eraqi, M. (2008). Local communities' attitudes towards impacts of tourism development in Egypt. Tourism Analysis, 12, pp. 191-200

[22] Garson, D. G. (2008). Validity. Retrieved May 8th, 2008, from http://www2.chass.ncsu.edu/garson/PA765/validity.htm.

[23] Gursoy, D. and Rutherford, D. (2004). Host attitudes toward tourism: An improved structural modeling approach. Annals of Tourism Research, 31(3), pp. 495-516

[24] Hall, C. M. and Lew, A. A. (1998). The geography of sustainable development; An introduction, In Hall C.M. and Lew A.A. (eds) Sustainable Tourism: A Geographical Perspective (pp. 1-12). Harlow: Longman

[25] Haywood, K.M. (1988). Responsible and responsive tourism planning in the community. Tourism Management 9(2), pp. 105-118

[26] Israel, G.D. (1992). Determining sample size. Program Evaluation and Organizational Development, IFAS, University of Florida, PEOD-5 (November), 1-7.

[27] Jones, D.L., Jurowski, C. and Uysal, M. (2000). Host community residents' attitudes: A comparison of environmental viewpoints. Tourism and Hospitality Research, 2(2), pp. 129-155.

[28] Kaiser, H.F. (1974). An index of factorial simplicity. Psychometrika, 39(1), pp. 31-36.

[29] Kaiser, H.F. (1960). The application of electronic computers to factor analysis. Educational and Psychological Measurement, 20, pp. 141-151.

[30] Kayat, K. (2002). Power, social exchanges and tourism in Langkawi: Rethinking residents' perceptions. International Journal of Tourism Research, 4, pp. 171-191.

[31] King B., Pizam, A. and Milman, A. (1993). Social impacts of tourism: Host perceptions. Annals of Tourism Research, 20, pp. 650-665.

[32] Liu. J. and Var, T. (1986). Resident attitudes toward tourism impacts in Havaii. Annals of Tourism Research, 13, pp. 193-214. 
[33] Madrigal, R. (1993). A tale of two cities. Annals of Tourism Research, 20(2), pp. 336-353.

[34] McCool, S. F. and Martin, S. R. (1994). Community attachment and attitudes toward tourism development. Journal of Travel Research, 32(3), pp. 29-34.

[35] McGehee, N. and. Andereck, K. (2004). Factors predicting rural residents support of tourism. Journal of Travel Research, 43, pp. 131-140.

[36] Milman, A. and Pizam, A. (1988). Social impacts of tourism on Central Florida. Annals of Tourism Research, 15(2), pp. 191-204.

[37] Murphy, P. (1985). Tourism: A Community Approach. London, Methuen.

[38] Norman, G. and Streiner, D. (1994). Biostatistics: The Bare Essentials. St Louis, Mo: Mosby.

[39] Nunnally, J. C. (1978). Psychometric Theory (2nd Ed.). New York, NY: McGraw-Hill.

[40] Nunkoo, R., Ramkissoon, H., Gursoy, D. and Chi, C.G., (2009). A model for understanding residents' support for tourism in small islands. Proc. of the International CHRIE Conference-Refereed Track, Event 18, Scholar Works at the University of Massachusetts, Amherst, pp. 1-8.

[41] Pedhazur, E. and Schmelkin, L. (1991). Measurement, Design and Analysis: An Integrated Approach. Hiltsdale, NJ: Lawrence Erlbaum Associates.

[42] Perdue, R., Long, P. and Allen, L. (1991). Resident support for tourism development. Annals of Tourism Research, 17, pp. 586-599.

[43] Petrić, L. and Mrnjavac Ž. (2004). Turistička destinacija kao lokalno ukorijenjeni sustav: analogija između modela turističke destinacije i industrijskog distrikta. Turizam, 51(4), pp. 375-387.

[44] Snaith, T. and Haley, A. (1999). Residents' opinions of tourism development in the historic city of York, England. Tourism Management, 20, pp. 595-603.

[45] Southgate, C. and Sharpley, R. (2002). Tourism, Development and the Environment. In Sharpley, R., Telfer, D.J. (Ed.), Tourism and Development - Concepts and Issues (pp. 231-264). Channel View Publications.

[46] Teye, V., Somez, S. F. and Sirakaya, E. (2002). Residents' attitudes toward tourism development. Annals of Tourism Research, 29(3), pp. 668-88

[47] Timothy, D.J. (1998). Cooperative tourism planning in a developing destination. Journal of Sustainable Tourism, 6(1), pp. 52-68

[48] Timothy, D.J. (2002). Tourism and Community Development Issues. In Sharpley R., Telfer, D.J., (Ed.), Tourism and Development. Channel View Publications, pp. 149-164.

[49] Um, S. and Crompton, J. L.(1987). Measuring resident's attachment levels in a host community. Journal of Travel Research, 25(3), pp. 27-29. 